\title{
The antimicrobial and antioxidant property, GC-MS analysis of non-edible oil-seed cakes of neem, madhuca, and simarouba
}

\author{
A. VasudhaUdupa', Balakrishna Gowda ${ }^{2}$, B. E. Kumarswammy ${ }^{1}$ and M. B. Shivanna ${ }^{1 *}$ (])
}

\begin{abstract}
Background: The antimicrobial activity against clinically and agriculturally important microorganisms, antioxidant property and chemical profiling of acetone crude extracts of non-edible oil-seed cakes of neem (Azadirachta indica A. Juss), madhuca (Madhuca longifolia syn. Madhuca indica Gmelin) and simarouba (Simarouba glauca DC) obtained by hot and cold extraction methods were tested in-vitro.

Results: The hot neem and cold acetone extracts of madhuca and simarouba were inhibitory to Staphylococcus aureus. The enteric pathogens-Enterococcus faecalis and Salmonella enterica were inhibited by both hot and cold extracts of simarouba cake. Fusarium oxysporum and Colletotrichum capsici were sensitive to oil-seed cake extracts of madhuca and simarouba cake extracts followed by neem cake extract. The Aspergillus flavus was highly sensitive to neem followed by madhuca and simarouba extracts. The cyclic voltammetry of all extracts indicated the presence of oxidation peaks at different Epa values suggesting the presence of antioxidant ability. The GC-MS profile revealed the presence of pharmacologically important essential compounds.
\end{abstract}

Conclusion: The study revealed the presence of bioactive compounds in non-edible oil-seed cakes that could be exploited for human welfare.

Keywords: Neem cake, Madhuca cake, Simarouba cake, Antimicrobial activity, Crude cake extracts, Cyclic voltammeter, Phytochemicals, GC-MS profile

\section{Background}

India is a home to several non-edible oil-yielding plant species such as jatropha, castor, pongamia, neem, madhuca, and simarouba (Padhi and Singh 2011). Oil-seeds produced in such plant species are the potential source for biodiesel production (Gubitz et al. 1999; Sharmin et al. 2006; Martin et al. 2010). The biodiesel sourced from plants is better than the conventional diesel fuel in their physico-chemical properties and biodegradability (Knothe 2006; Scott et al. 2008). The above features

\footnotetext{
*Correspondence: mbshivanna@yahoo.co.uk

${ }^{1}$ Department of PG Studies and Research in Applied Botany, Jnana Sahyadri, Kuvempu University, Shankaraghatta, Shivamogga 577 451, India

Full list of author information is available at the end of the article
}

of biodiesel prompted the increased utilization of nonedible oil-seeds to produce biodiesel. The oil seed-cake, the by-product of biodiesel industry from oil-seeds, can neither be directly utilized as an animal feed nor in agriculture due to the presence of certain phytotoxic compounds in them (Makkar et al. 1998; Akintayo 2004). However, the oil-seed cakes are rich in cellulose, hemicellulose, and lignin (Culcuoglu et al. 2002) besides high nitrogen, phosphorus, and potassium contents and hence cakes could be used as the source of organic fertilizers. Several toxic and non-toxic phytochemicals contained in oil-seed cakes could be isolated and utilized in various industries (Prasad et al. 2005; Govindaraju et al. 2009; Kumari et al. 2013).

The indiscriminate use of synthetic chemical compounds and antibiotics for the control of plant and 
human pathogens poses severe problems to human and environmental health, resulting in the development of multi-drug-resistant pathogens and contamination of the food chain in the ecosystem (Crouse 1998). In contrast to this, the above plant-based metabolites are biodegradable and could become the best source alternative to synthetic chemicals and antibiotics (Joshi et al. 2011; Parimala and Shoba 2014).

The oil-yielding plant species such as neem, madhuca, and simarouba also find application in traditional medicinal preparations since they contain diverse phytochemicals with promising therapeutic value for treating several infectious diseases (Govindachari 1992; Mansi and Gaikwad 2011). Neem (Azadirachta indica A. Juss, family Meliaceae) is a predominant source of limonoids (Kavathekar 2003) like azadirachtin $(0.2-0.6 \%, \mathrm{w} / \mathrm{v})$ in the seed kernels (Govindachari 1992). Madhuca (Madhuca longifolia syn. Madhuca indica Gmelin, family Sapotaceae) is the primary source of semisolid fat along with other phytochemicals, such as saponins (Kumar et al. 2011). Simarouba (Simarouba glauca DC, family Simaroubaceae) also the rich source of oil (60\%) contains the bitter terpenoids and quassinoids in the oil-cake (Severan 1953). The seeds, as well as seed-cakes of neem, madhuca, and simarouba, are being incorporated into the soil to control plant pathogenic nematodes and insects (Prasad et al. 2005; Saha et al. 2010; Ashraf and Khan 2010; Rizvi et al. 2012).

The utilization of non-edible oil-seed-cakes is mainly for their role in protecting plants from soil-borne phytopathogens, nematodes, and insect pests (Rameshchandran et al. 2007). Further, the literature survey indicated that the oil-seed cakes of the neem, madhuca, and simarouba had not been studied for their antimicrobial and antioxidant properties, as well as the phytotoxicity. The present study aims at determining the antibacterial, antifungal, and antioxidant activities in extracts of oilseed-cakes of neem, madhuca, and simarouba and the chemical profiling of oil-cakes by GC-MS analysis.

\section{Methods}

\section{Solvent extraction of oil-seed cakes}

The oil-seed-cakes of neem, madhuca, and simarouba were collected from the Biofuel Production Unit, Hassan, Karnataka. The above oil-seed cakes were air-dried under ambient conditions in the shade for 5-7 days and stored in air-tight zip-lock covers at $5^{\circ} \mathrm{C}$. The oil-seed-cake $(500 \mathrm{~g})$ of each plant species was subjected to sequential hot extraction with hexane, ethyl acetate, acetone, and water for $24 \mathrm{~h}$ using the Soxhlet apparatus (Soxhlet 1879). Another set consisting of the above cake samples was also extracted with the hexane, ethyl acetate, acetone, and water solvents, but in the cold for $24 \mathrm{~h}$, using a rotary shaker $(120 \mathrm{rpm})$. The crude extracts were recovered under vacuum and stored at $4{ }^{\circ} \mathrm{C}$ in air-tight vials, until use.

\section{Phytochemical assay}

The acetone extracts of oil-seed cakes obtained from both methods were subjected to qualitative phytochemical analysis (Sasidharan et al. 2011). The stock solution of each extract was prepared by dissolving the crude residue of plant extract $(100 \mathrm{mg})$ separately in DMSO and stored in glass bottles. The stock solutions were then subjected to the assay of alkaloids, flavonoids, flavones, phenols, sterols, triterpenoids, coumarins, glycosides, tannins, lignin, quinones, anthraquinones, plobatannins, volatile oil and saponins, and primary metabolites, as well.

\section{Antimicrobial assay}

The in vitro antimicrobial activity of acetone extracts of oil-seed-cakes was determined by the well diffusion method (Bauer et al. 1966). The bacterial test organisms selected were Escherichia coli (MTCC 1559), Salmonella enterica (MTCC 738), Staphylococcus aureus (MTCC 902), and Enterococcus faecalis (MTCC 439). The test plant pathogenic fungal isolates included Fusarium oxysporum (MTCC 2485), Colletotrichum capsci, C. graminicola, and the human pathogens included Aspergillus flavus (MTCC 2813) and Candida albicans (MTCC 3017). The bio-control agent Pseudomonas fluorescence (MTCC 9768) was also included.

All the bacterial isolates were cultured in the nutrient broth for $16 \mathrm{~h}$, and $100 \mu \mathrm{L}$ of each culture was spread on a nutrient agar medium. One loop-full of three-day-old sporulating fungal culture was suspended in sterile water $(1 \mathrm{~mL})$, and $100 \mu \mathrm{L}$ of each mixture spread separately on potato dextrose agar. The antibacterial standards (ampicillin, chloramphenicol, or ciprofloxacin) and antifungal standards (fluconazole, griseofulvin), or bavistin (5 mg each) taken separately in DMSO $(1 \mathrm{~mL})$ were considered as positive controls. At the same time, only DMSO was recognized as the negative control. The stock solution of each extract in DMSO $\left(200 \mathrm{mg} \mathrm{mL}^{-1}\right)$ was prepared and diluted to obtain the concentration of $200,100,50$, or $25 \%$. The individual extract was placed into $5 \mathrm{~mm}$ dia. wells in the agar medium and incubated at $37^{\circ} \mathrm{C}$ for $24 \mathrm{~h}$ in case of test bacteria and $30^{\circ} \mathrm{C}$ for $72 \mathrm{~h}$ in case of fungal isolates. The clear zone of inhibition (ZI, $\mathrm{mm}$ ) around the well indicated the antimicrobial activity of the extract.

\section{Assay of the electrochemical potential of extracts}

The electrochemical potential of the acetone extract of oil-seed cakes was determined by the cyclic voltammetry (CV model CHI660c potentiostat) (Arulpriya et al. 2010). The analytical system consisted of a two-compartment 
Pyrex cell with a conventional three-electrode configuration, a carbon paste working electrode (Teflon tube $3 \mathrm{~mm}$ dia) activated by mixing $70 \%$ graphite powder and $30 \%$ silicon oil, a platinum wire counter electrode and a saturated calomel reference electrode. About $10 \mathrm{~mL}$ of phosphate buffer $(\mathrm{pH})$ (supporting solution) was dispensed into an electrochemical cell to record the voltammogram of the blank. The appropriate volume $(2 \mathrm{mM})$ of acetone extract was added to the supporting solution, and CV measurements were recorded at positive potential $(-0.2$ to +1.0$)$ at the scan rate of 50 to $300 \mathrm{mVs}^{-1}$ at room temperature.

\section{GC-MS analysis}

The acetone extracts of neem, madhuca or simarouba oil-seed cakes were analyzed for their chemical constituents by a combined Gas Chromatography (GC) (Thermo Scientific Trace 1310) and triple quad Mass Spectrometer (MS) (Thermo Scientific TSQ 8000) using DB 5MS (30 cm length, $0.250 \mathrm{~mm}$ ID) silica column and helium as a carrier gas. One microliter of the sample was injected into the column at $250^{\circ} \mathrm{C}$. A column temperature initiated the GC program at $40^{\circ} \mathrm{C}$ for $2 \mathrm{~min}$. and increased to $240^{\circ} \mathrm{C}$ at $5^{\circ} \mathrm{C} \mathrm{m}^{-1}$ rate.

Further, the temperature was increased to $300^{\circ} \mathrm{C}$ at a scan range of 50 and $600 \mathrm{Da}$. The total period of $47 \mathrm{~min}$. was required to complete the entire run. The data were analyzed by the software Calibur 4.0, and chromatograms obtained were analyzed and identified by matching their mass spectral fragmentation patterns with a database deposited at the National Institute of Standards and Technology Mass spectral database (NIST 2.2) library.

\section{Statistical analysis}

Each assay was performed in three replicates with a completely randomized design, and the Zone of Inhibition (ZI) was expressed as the mean \pm standard error.

\section{Results}

\section{Phytochemical screening of oil-seed cakes}

The oil-seed-cakes of neem, madhuca, and simarouba upon extraction by cold and hot solvents yielded primary and secondary metabolites. The hot extraction method produced more volume of extracts when compared to the cold extraction method. The acetone extracts yielded polar aprotic phytochemicals. The oil-seed-cakes of selected species tested positive for alkaloids, flavonoids, glycosides, lignins, phenols, sterols, tannins, and triterpenoids. Coumarins were documented only in neem oilseed cake. Flavones and lignins were present in the cold and hot acetone extract, respectively, in all seed-cake extracts. Quinones and anthraquinones in madhuca and simarouba oil-seed cakes were extractable only by the hot acetone.

\section{Antibacterial activities of oil-seed cakes}

Hot acetone fraction of neem oil-seed-cake produced prominent ZI to S. aureus. In contrast, the cold acetone fraction strongly inhibited $E$. faecalis, which was comparable to that of the standard antibiotic amoxicillin. However, cold acetone fraction was less active for $S$. aureus and E. faecalis, respectively. This observation pointed out that compounds extracted into cold acetone could be acting with a different mode of action depending on the test isolate. Alternatively, a high extract concentration of $200 \%$ could be required to produce a high ZI (Table 1).

Cold acetone fraction of madhuca oil-seed-cake exhibited the ZI of $8.1 \mathrm{~mm}$ to $S$. aureus, which is slightly less effective than amoxicillin $(11 \mathrm{~mm})$. On the other hand, hot acetone fraction failed to inhibit test isolates, except $P$. fluorescence. In the case of simarouba oil-seed-cake, cold acetone extract produced a good ZI comparable to that of amoxicillin. In contrast, the hot acetone extract at $100 \%$ caused high ZI $(12.2 \mathrm{~mm})$ to $S$. enteritica, which is similar to that of the amoxicillin. A further increase to a concentration of up to $200 \%$ increased inhibition to $18.9 \mathrm{~mm}$. On the other hand, cold acetone extract was the least effective for E. coli and P. fluorescence even at an elevated concentration.

The cold acetone fraction of simaouba oil-seed cake at high concentration also inhibited the colony growth of S.aureus, E. faecalis, and S. enterica, comparable to amoxicillin control (Table 1). The above observations indicated that inhibition of colony culture of test organisms increased with an increase in the concentration of the extract. Among the three antibiotic standards used, ciprofloxacin followed by chloramphenicol was most effective by producing the high zone of inhibition.

\section{Antifungal activity of oil-seed cakes}

The oil-seed cakes of selected plant species also showed antifungal activity to certain test fungal species. Both the hot and cold extractions were active for at least three fungal species. Fusarium. oxysporum, C. capsici, and $A$. flavus as well as $C$. albicans, were sensitive to all the oil-seed-cake extracts. The colony growth of $F$. oxysporum and A. flavus was inhibited by cold and hot acetone extracts of neem cake, much like that exhibited by standards-fluconazole and bavistin (Table 2). While hot acetone extract was efficacious for C. capsici, it was ineffective for $C$. albicans. The madhuca oil-seed-cake extract was comparatively similar to standards fluconazole and bavistin for $F$. oxysporum. Cold acetone extracts inhibited the growth of C. albicans. (Table 2). 
Table 1 Antibacterial activity of cold and hot acetone extracts of neem, madhuca, and simarouba oil-seed cakes

\begin{tabular}{|c|c|c|c|c|c|c|}
\hline \multirow{2}{*}{$\begin{array}{l}\text { Oil-seed cake / extraction solvents/ } \\
\text { Standard antibiotics }\end{array}$} & \multicolumn{6}{|c|}{$\mathrm{ZI}(\mathrm{mm})$ in test bacterial isolates ${ }^{1}$} \\
\hline & $\begin{array}{l}\text { Extract } \\
\text { Conc (\%) }\end{array}$ & $\mathrm{Sa}^{2}$ & $\mathrm{Ef}^{2}$ & $\mathrm{Se}^{3}$ & $\mathrm{Ec}^{3}$ & $\mathrm{Pf}^{3}$ \\
\hline \multicolumn{7}{|l|}{ Neem seed-cake } \\
\hline \multicolumn{7}{|l|}{ Cold-acetone } \\
\hline & 100 & 0 & $9.8 \pm 0.14$ & $2.9 \pm 0.12$ & $2.2 \pm 0.17$ & $1.2 \pm 0.14$ \\
\hline & 200 & $2.9 \pm 0.008$ & $12.0 \pm 0.11$ & $4.9 \pm 0.08$ & $5.2 \pm 0.14$ & $5.3 \pm 0.11$ \\
\hline \multicolumn{7}{|l|}{ Hot-acetone } \\
\hline & 100 & $10.0 \pm 0.08$ & 0 & 0 & $3.0 \pm 0.08$ & $1.1 \pm 0.08$ \\
\hline & 200 & $15.0 \pm 0.11$ & $1.3 \pm 0.11$ & $4.4 \pm 0.08$ & $5.4 \pm 0.08$ & $3.0 \pm 0.11$ \\
\hline \multicolumn{7}{|l|}{ Madhuca seed-cake } \\
\hline Cold-acetone $^{4}$ & 200 & $8.1 \pm 0.1$ & 0 & $2.0 \pm 0.08$ & $2.2 \pm 0.1$ & $2.2 \pm 0.1$ \\
\hline \multicolumn{7}{|l|}{ Simarouba seed-cake } \\
\hline \multicolumn{7}{|l|}{ Cold-acetone } \\
\hline & 100 & $10.0 \pm 0.08$ & $7.1 \pm 0.12$ & $4.2 \pm 0.12$ & 0 & $1.3 \pm 0.8$ \\
\hline & 200 & $13.9 \pm 0.08$ & $10 \pm 0.11$ & $18.0 \pm 0.15$ & $2.2 \pm 0.08$ & $3.2 \pm 0.12$ \\
\hline \multicolumn{7}{|l|}{ Hot-acetone } \\
\hline & 100 & $1.2 \pm 0.12$ & $1.1 \pm 0.08$ & $12.2 \pm 0.12$ & 0 & $0.5 \pm 0.03$ \\
\hline & 200 & $2.4 \pm 0.08$ & $3.4 \pm 0.08$ & $18.9 \pm 0.08$ & $5.0 \pm 0.08$ & $1.3 \pm 0.1$ \\
\hline \multicolumn{7}{|l|}{ Standards } \\
\hline Amoxicillin & $5^{5}$ & $11.0 \pm 0.1$ & $10.0 \pm 0.14$ & $12.0 \pm 0.12$ & $11.0 \pm 0.17$ & $15 \pm 0.08$ \\
\hline Ciprofloxacin & 5 & $32.0 \pm 0.1$ & $30.0 \pm 0.14$ & $32.0 \pm 0.12$ & $30.0 \pm 0.17$ & $30.0 \pm 0.08$ \\
\hline Chloramphenicol & 5 & $20.0 \pm 0.1$ & $20.0 \pm 0.14$ & $21.0 \pm 0.12$ & $21.0 \pm 0.17$ & $20.0 \pm 0.08$ \\
\hline DMSO & $20^{6}$ & 0 & 0 & 0 & 0 & 0 \\
\hline \multicolumn{7}{|c|}{1 Values are mean of three replicates $(\mathrm{n}=3)$; crude extracts were dissolved in DMSO (200 $\mathrm{mg}$ in $1 \mathrm{ml}$ of DMSO) Each well received $20 \mu \mathrm{Ll}^{-1}\left(4 \mathrm{mg} \mathrm{well}^{-1}\right)$} \\
\hline \multicolumn{7}{|c|}{2 Gram-positive bacteria; Sa-Staphylococcus aureus and Ef-Enterococcus faecalis } \\
\hline \multicolumn{7}{|c|}{${ }^{3}$ Gram-negative bacteria: Se- Salmonella enterica, Ec- Escherichia coli and Pf- Pseudomonas fluorescens } \\
\hline \multicolumn{7}{|c|}{${ }^{4}$ Cold acetone extract of madhuca oil-seed cake inhibited only S. aureus at $100 \%(\mathrm{Zl}=5.1 \pm 0.01)$} \\
\hline \multicolumn{7}{|c|}{${ }^{5} 5 \mathrm{mg}$ of standards dissolved in $1 \mathrm{ml}$ of DMSO } \\
\hline${ }^{6} 20 \mu \mathrm{L}$ of DMSO (negative control) added & 1 to b & & & & & \\
\hline
\end{tabular}

\section{The electrochemical potential of extracts}

An irreversible anodic peak was produced due to hot acetone extract of neem at $0.42 \mathrm{~V}$, but no peaks were recorded in the cold extract, which could be due to the absence of compounds with observable redox potential (Fig. 1). On the other hand, the voltammogram of a hot extract of simarouba showed two peaks at $0.19 \mathrm{~V}$ and $0.68 \mathrm{~V}$, while one peak at 0.22 was observed in the cold extract at $300 \mathrm{Vs}^{-1}$ scan rates. Both the hot and cold acetone extracts of madhuca oil-seed cake produced similar peaks at $0.19 \mathrm{~V}$ (Fig. 1).

\section{GC-MS analysis}

The chemical profiling of solvent extracts of non-edible oil-seed cakes of neem, madhuca, and simarouba by GC-MS analysis revealed the presence of several phytochemicals (Figs. 2, 3, 4). The NIST and PubChem database search of these chemicals indicated that they were documented for antimicrobial, antioxidant, anticancerous, and other pharmacological activities as well as pesticidal and herbicidal properties. The cold extraction of oil-seed cakes of neem and madhuca followed by simarouba yielded more number of compounds than the hot extraction method (Table 3, Fig. 4). The glycerine is the major chemical component in both the hot and cold acetone extracts of madhuca (78.15\% and $20.15 \%$, respectively) and hot acetone extract of neem (41.36\%). Diacetone, a hydroxyl ketone, is another major chemical present in relatively high content in both hot $(60.12 \%)$ and cold $(17.75 \%)$ acetone extracts of simarouba oil-seed cake. At the same time, $\alpha$-D-Glucopyranoside is the major component of neem cold acetone extract (21.65\%). Cis-13-Eicosenoic acid $(21.01 \%)$ an antifungal metabolite present in cold acetone extract of simarouba followed by madhuca and neem oil-seed cake (Table 3 ). The GC chromatograms of six extracts presented in Figs. 2, 3, 4 show the retention times in the column and the detected peaks which 
Table 2 Antifungal activity of cold and hot acetone extracts of neem, madhuca, and simarouba oil-seed cake

\begin{tabular}{|c|c|c|c|c|c|}
\hline \multirow{2}{*}{$\begin{array}{l}\text { Oil-seed cake/extraction solvents/ } \\
\text { Standard antibiotics }\end{array}$} & \multicolumn{5}{|c|}{$\mathrm{ZI}(\mathrm{mm})$ in test fungal isolates ${ }^{1}$} \\
\hline & $\begin{array}{l}\text { Extract } \\
\text { Conc (\%) }\end{array}$ & $\mathrm{Fo}^{2}$ & $\mathrm{Cc}^{2}$ & $\mathrm{Af}^{3}$ & $\mathrm{Ca}^{3}$ \\
\hline \multicolumn{6}{|l|}{ Neem seed-cake } \\
\hline \multirow[t]{3}{*}{ Cold-acetone } & 50 & 0 & 0 & $3.0 \pm 0.1$ & 0 \\
\hline & 100 & $8.0 \pm 0.1$ & 0 & $6.0 \pm 0.1$ & 0 \\
\hline & 200 & $13.0 \pm 0.1$ & 0 & $13.0 \pm 0.1$ & 0 \\
\hline \multirow[t]{3}{*}{ Hot-acetone } & 50 & $6.0 \pm 0.15$ & $4.0 \pm 0.1$ & 0 & 0 \\
\hline & 100 & $8.0 \pm 0.05$ & $9.2 \pm 0.1$ & $4.0 \pm 0.05$ & 0 \\
\hline & 200 & $11.2 \pm 0.1$ & $14.16 \pm 0.08$ & $11.2 \pm 0.1$ & 0 \\
\hline \multicolumn{6}{|l|}{ Madhuca seed-cake } \\
\hline \multirow[t]{3}{*}{ Cold-acetone } & 50 & $6.0 \pm 0.1$ & 0 & 0 & 0 \\
\hline & 100 & $11.0 \pm 0.1$ & $5.0 \pm 0.08$ & 0 & $2.0 \pm 0.1$ \\
\hline & 200 & $17.03 \pm 0.1$ & $11.2 \pm 0.1$ & $7.0 \pm 0.1$ & $5.0 \pm 0.1$ \\
\hline \multirow[t]{3}{*}{ Hot-acetone } & 50 & $4.0 \pm 0.1$ & 0 & 0 & 0 \\
\hline & 100 & $9.0 \pm 0.05$ & $5.0 \pm 0.1$ & 0 & 0 \\
\hline & 200 & $12.1 \pm 0.1$ & $14.2 \pm 0.1$ & $7.0 \pm 0.1$ & 0 \\
\hline \multicolumn{6}{|l|}{ Simarouba seed-cake } \\
\hline \multirow[t]{3}{*}{ Cold-acetone } & 50 & 0 & $7.0 \pm 0.08$ & 0 & 0 \\
\hline & 100 & $7.0 \pm 0.1$ & $10.0 \pm 0.08$ & 0 & 0 \\
\hline & 200 & $14.0 \pm 0.1$ & $15.0 \pm 0.1$ & 0 & 0 \\
\hline \multirow[t]{3}{*}{ Hot-acetone } & 50 & $9.0 \pm 0.1$ & 0 & $2.0 \pm 0.1$ & 0 \\
\hline & 100 & $11.0 \pm 0.05$ & $4.0 \pm 0.1$ & $4.0 \pm 0.1$ & 0 \\
\hline & 200 & $14.0 \pm 0.1$ & $9.0 \pm 0.1$ & $6.0 \pm 0.1$ & 0 \\
\hline \multicolumn{6}{|l|}{ Standards } \\
\hline Fluconazole & $5^{4}$ & $6.2 \pm 0.1$ & $5.2 \pm 0.1$ & $5.6 \pm 0.1$ & $6.6 \pm 0.1$ \\
\hline Bavistin & 5 & $12.0 \pm 0.1$ & $11.0 \pm 0.1$ & $12.0 \pm 0.1$ & 0 \\
\hline DMSO & $20^{5}$ & 0 & 0 & 0 & 0 \\
\hline
\end{tabular}

are correspond to the bioactive phytochemicals present in the extract. Some of the bioactive compounds isolated were illustrated in the Fig. 5.

\section{Discussion}

The potential of oil-seed cake extracts of neem, madhuca, and simarouba as antibacterial, antifungal and antioxidant, along with GC-MS profile was studied. The acetone extract of all three oil-seed cakes had high bioactivities. Acetone extracts both hydrophilic and lipophilic components of plants and is less toxic to bioassays (Das et al. 2010). The antibacterial activity depended on the chemical constituents of oil-seed-cake and the method of extraction. According to Eloff (1998), acetone is the most suitable solvent for the removal of both polar and nonpolar phytochemicals and microbial inhibitors. The hot neem cake extract was more efficient in inhibiting the $S$. aureus and E. faecalis than the cold extract. The observed antibacterial activity of neem cake was evidenced with the presence of several biologically active limonoids such as azadirachtin A, and triterpenoids like salanin, nimbin, nimbidin, and gedunnin (Govindachari 1992). Salanin, the primary compound in neem cake, was shown with excellent antibacterial activity to meat-borne bacteria and hence is known as the natural preservative for meat storage (Sarone and Nicholetti 2013).

Cold acetone fraction of madhuca oil-seed-cake was inhibitory to $S$. aureus, but the hot extract was not effective to the bacterial pathogen. The reduced antibacterial activity in hot extracts as compared to the cold ones could probably hint at the denaturation of certain thermolabile compounds with antibacterial activity (Adeshina et al. 2011; Rubila and Ranghanathan 2014). The madhuca cake contains compounds like saponins, 


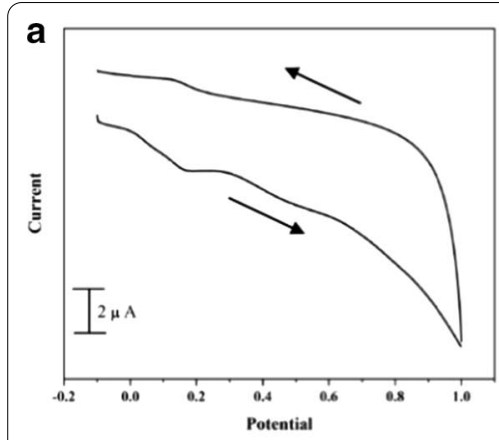

b

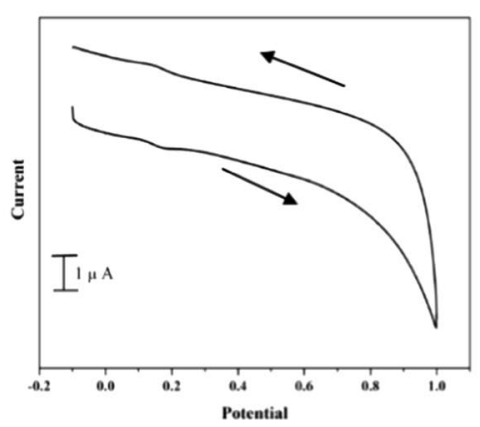

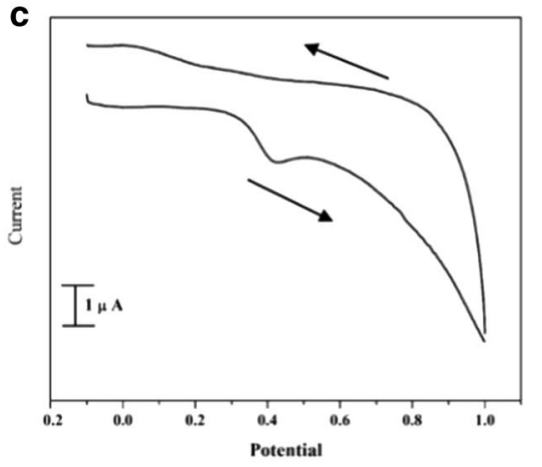
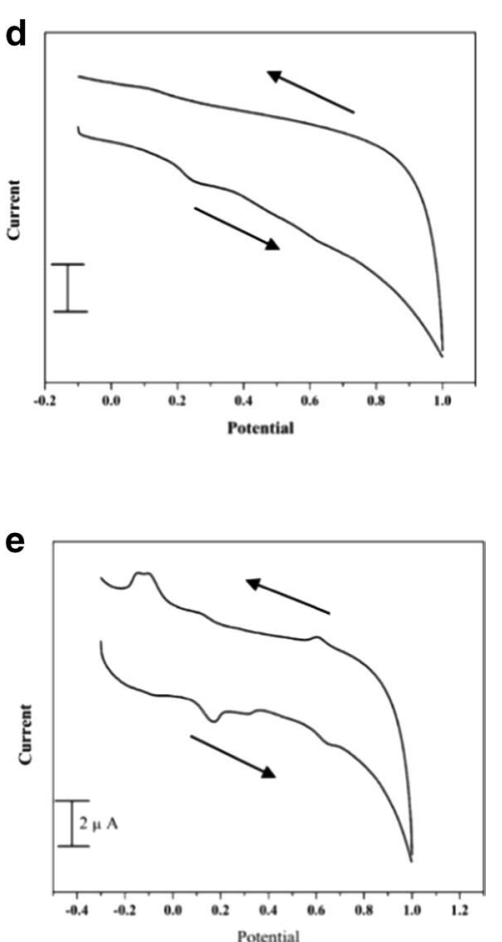

Fig. 1 Voltammograms of (a) Madhuca cold ( b) Madhuca hot (c) Neem hot ( d) simarouba cold and (e) simarouba hot acetone extracts

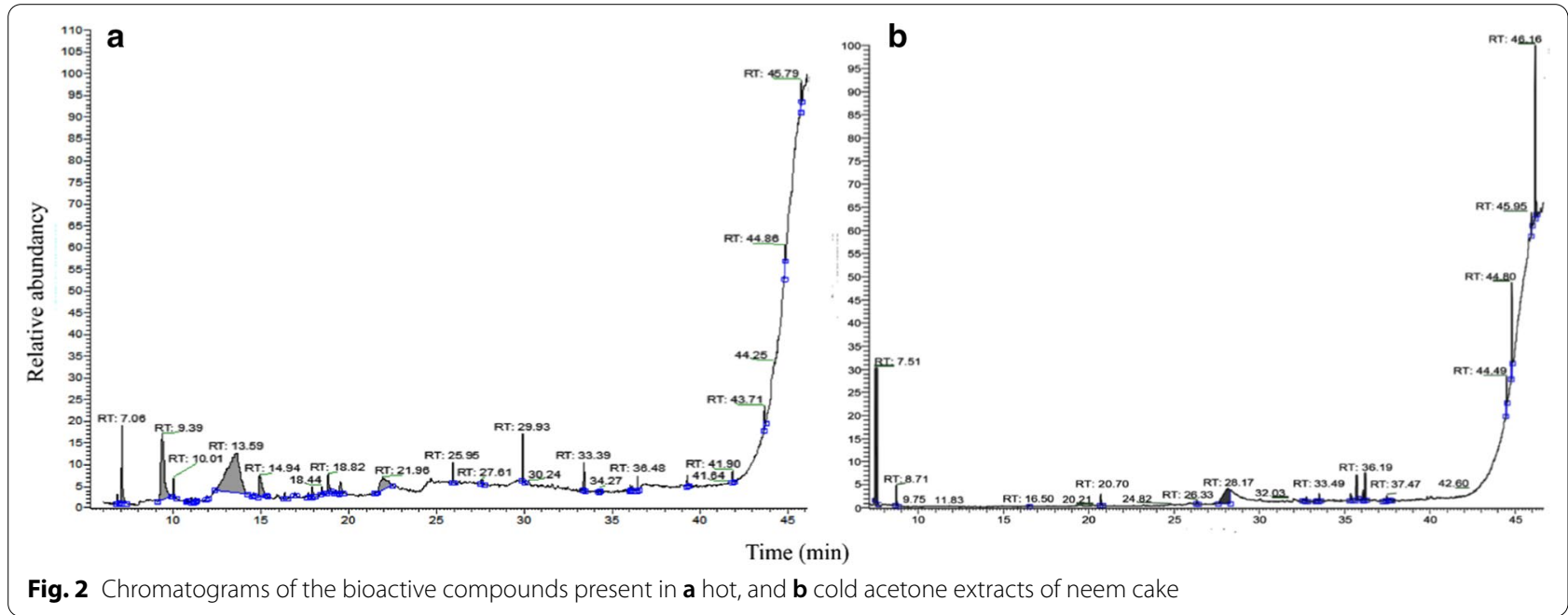

flavonoids, and glycosides that have been known for their antibacterial activity (Yadav and Singh 2012). However, certain extracts extracted either by hot or cold methods had a relative activity like that of amoxicillin. Amoxicillin, being bactericidal is shown to inhibit bacterial cell wall synthesis (Harold 1974). Some of the oil seed-cake extracts showing good inhibition ability might be having the same mode of action similar to that of amoxicillin. Previous reports have shown that specific metabolites containing alkaloids, flavonoids, and phenols inhibited the clinical pathogen S. aureus (Shinde and Mulay 2015). The optimal effectiveness of these secondary metabolites and their antimicrobial activity and exhibited mechanisms are not fully understood, although specific studies attempted to decipher the mechanism(s) involved. While alkaloids are microbicidal (Ghoshal et al. 1996), phenolic compounds such as flavones were inhibitory to the growth of A. niger and C. albicans and B. subtilis, E. coli, 


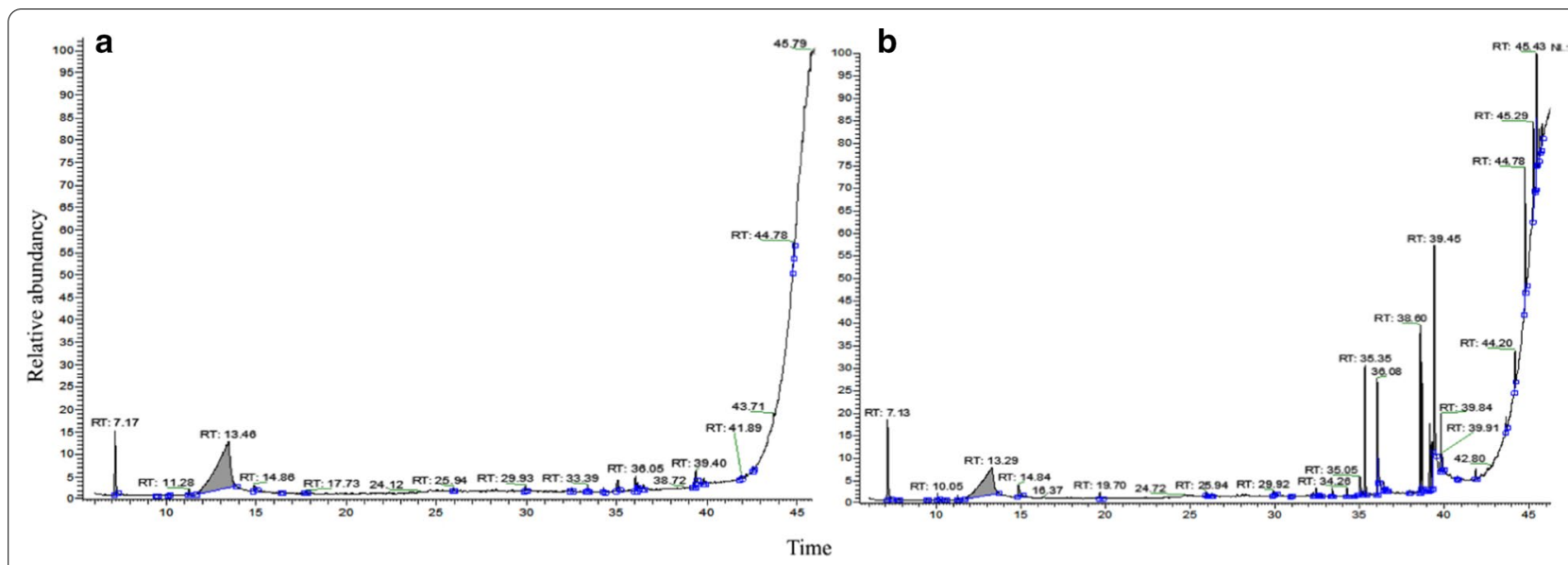

Fig. 3 Chromatograms of the bioactive compounds present in $\mathbf{a}$ hot, and $\mathbf{b}$ cold acetone extracts of madhuca cake
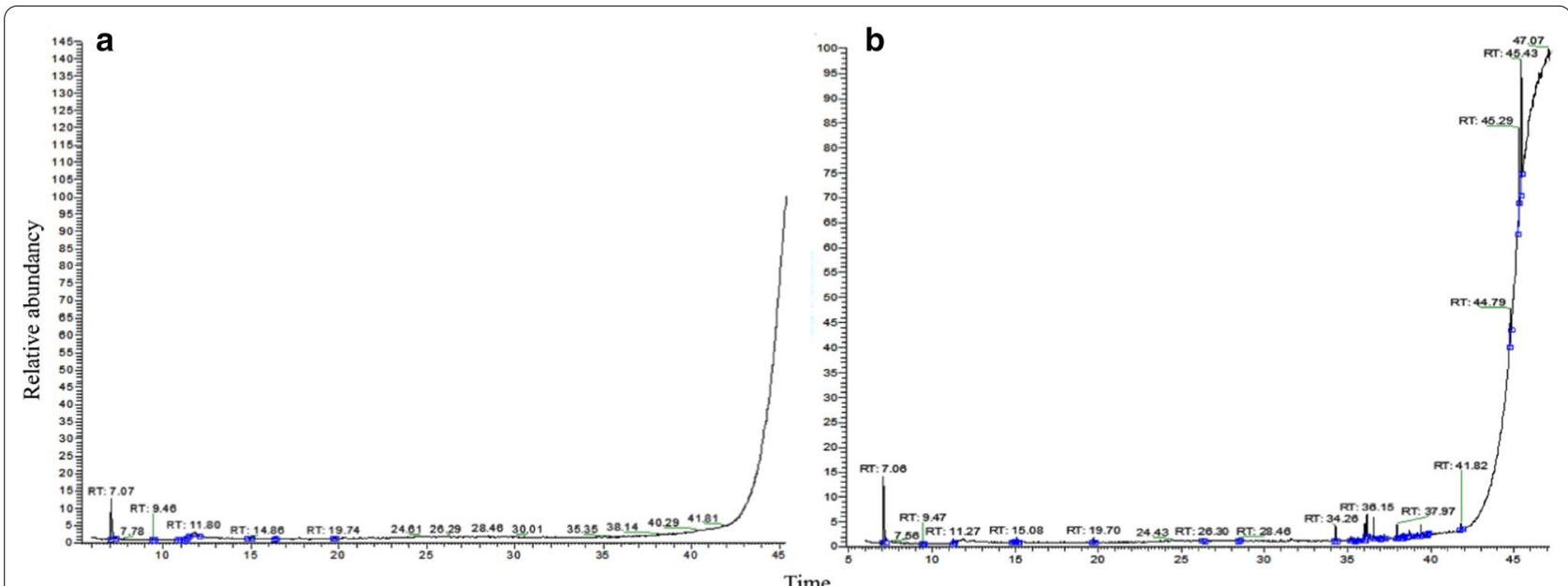

Fig. 4 Chromatograms of the bioactive compounds present in $\mathbf{a}$ hot, and $\mathbf{b}$ cold acetone extracts of simarouba cake

and S. epidermidis (Rahua et al. 2000). The mode(s) of action of flavonoids is related to the formation of complexes with extracellular soluble protein and bacterial cell walls (Gorniak et al. 2019) and inhibition of DNA gyrase and $\beta$-hydroxy-acyl carrier with protein dehydrogenase activity (Tsuchiya et al. 1996; Cushine and Lamb 2005).

On the other hand, tannins and terpenes are shown to act by disturbing the cell membrane integrity by binding with polysaccharides and proline-rich proteins. At the same time, coumarins affected the respiration rate of the cell (Chung et al. 1998; Shimada 2006). Previous studies also demonstrated the antibacterial activity in leaf extracts of neem, madhuca, and simarouba (Vinoth et al. 2012; Kathuria and Singh 2015; Valdes et al. 2008), and the findings of this study that oil-seed-cakes also exhibited antibacterial activity might throw light on the presence of similar compounds with antibacterial activity. An ethnobotanical investigation of simarouba indicated that leaf and bark extracts could be used to treat dysentery and malaria (Mansi and Gaikwad 2011). The findings of the present investigation also suggested that the oil-seed cake of simarouba inhibited enteric bacterial species used in the study (Table 2). This indicated the requirement of more detailed reviews to exploit the benefits of simarouba oil-seed cake, which is otherwise disposed-off unutilized. The active compound in simarouba, the quassinoids, is bitter triterpenoid with a polycyclic skeleton. The most known quassinoids in simarouba are alanthinone, glaucarubinone, and holacanthone along with benzoquinone, glaucarubine, melianone, simaroubidin, simaroubin, and sitosterol (Valdes et al. 2008). These quassinoids are shown with 


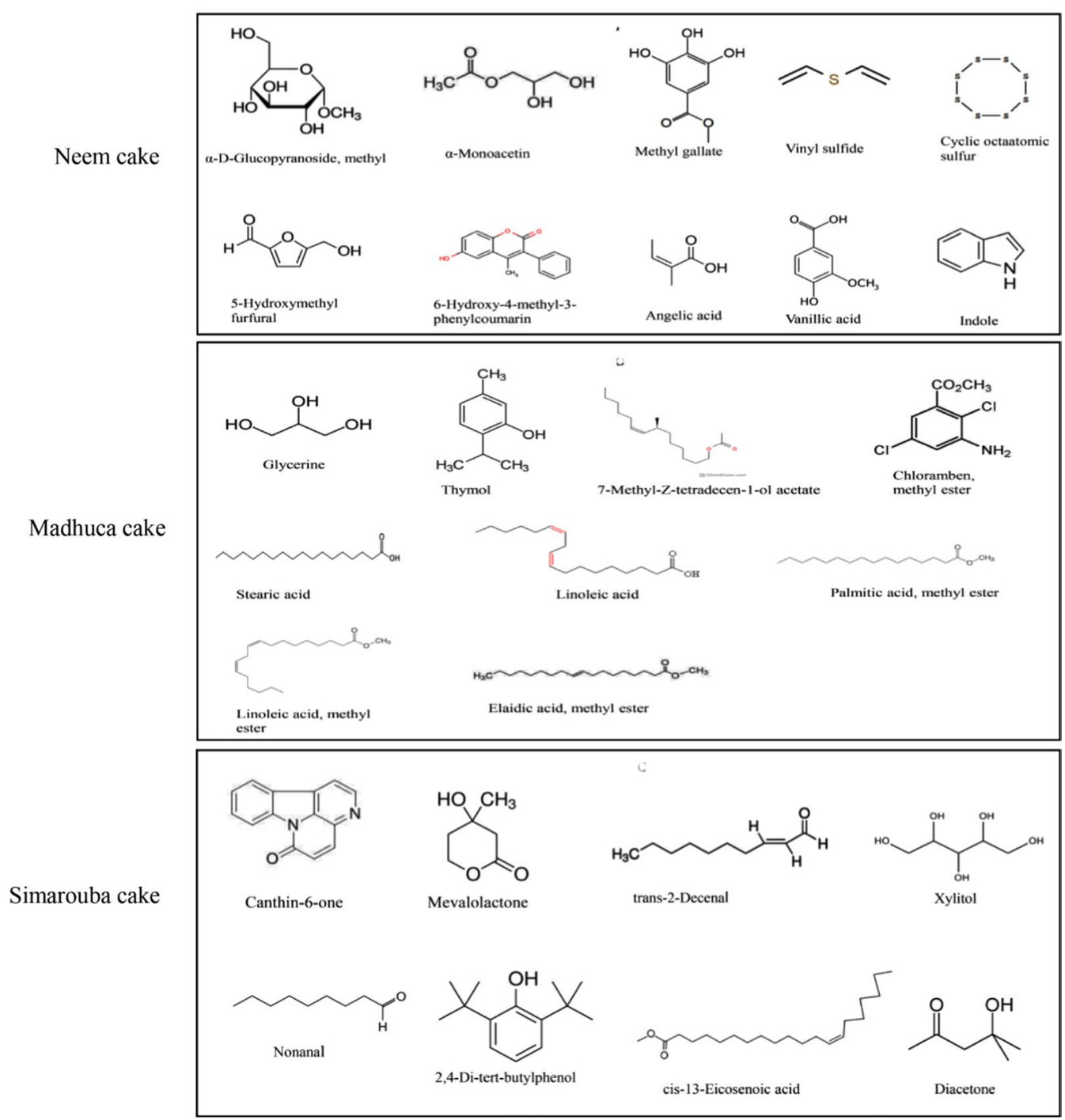

Fig. 5 Structure of some pharmaceutically active phytochemicals of non-edible oil-seed cakes of neem, madhuca, and simarouba

antimicrobial, antiamoebic, and antiprotozoal activities (Write 2005; Nurhannan et al. 2005), and the compound inhibited the synthesis of protein and nucleic acid in the malarial pathogen (Kirby et al. 1989).

The present study confirmed that the oil-seed-cakes of plant species were inhibitory to colony growth of $F$. oxysporum, C. capsci and C. albicans. The hot acetone simarouba oil-seed cake extract moderately inhibited A. flavus. This fungus is a common saprophyte capable of causing aspergillosis involving paranasal sinuses (Kameswaran and Raghunandan 2009) and aflatoxicosis in humans following the consumption of cereal grains and pulses contaminated with toxigenic strains of A.flavus (Abd Ek-Raheem et al 2014). The most notable view of the present study is the very high antifungal activity of the cold acetone extracts of madhuca against $F$. oxysporum, which had an inhibitory effect by nearly two folds to that of the systemic fungicide bavistin. Bavistin being a systemic fungicide is very useful to control Fusarium species, which caused wilt and other symptoms of disease in crop plants (Wani et al. 1982). The oil-seedcake extracts of neem, madhuca, or simarouba could be considered the promising sources of compounds to manage A.flavus contamination of grains (Kavitha et al. 2014). Except for the cold acetone extract from madhuca oil-seed cake, most oil-seed cake extracts of the above plant species were not highly effective for $C$. albicans. Hence, Candida albicans is a clinical pathogen capable of causing infections that persist for a long time in humans (Calderone and Clancy 2012). 
Table 3 GCMS profile of acetone extracts of oil-seed cakes of neem, madhuca, and simarouba with bioactivity

\begin{tabular}{|c|c|c|c|}
\hline Phytochemicals & $\begin{array}{l}\text { Oil-cakes } \\
\text { and methods } \\
\text { of extraction }\end{array}$ & Abundancy (\%) & Bioactivity \\
\hline \multirow[t]{4}{*}{ Glycerine } & Madhuca (hot) & 78.15 & $\begin{array}{l}\text { Antibacterial (Nalawade et al. 2015) Moisturizer to treat dry } \\
\text { rough, itchy skin. Disease resistant in plant (Zhang et al. } \\
\text { 2015) }\end{array}$ \\
\hline & Neem (hot) & 41.36 & \\
\hline & Simarouba (hot) & 29.67 & \\
\hline & Madhuca (cold) & 20.15 & \\
\hline \multirow[t]{5}{*}{ Diacetone } & Simarouba (hot) & 60.12 & $\begin{array}{l}\text { Antimicrobial, Cytotoxic and anticancer (antiproliferative) } \\
\text { (Güvensen et al. 2019) }\end{array}$ \\
\hline & Simarouba (cold) & 17.75 & \\
\hline & Madhuca (hot) & 6.78 & \\
\hline & Neem (hot) & 6.16 & \\
\hline & Madhuca (cold) & 4.02 & \\
\hline a-D-Glucopyranoside, metyl & Neem (cold) & 21.65 & $\begin{array}{l}\text { Antibacterial (Kawsar et al. 2015) } \\
\text { Anticancer (Lyantagaye 2013) }\end{array}$ \\
\hline \multirow[t]{3}{*}{ cis-13-Eicosenoic acid } & Simarouba (cold) & 21.01 & Antifungal (Ahsan et al. 2017) \\
\hline & Madhuca (cold) & 3.72 & \\
\hline & Neem (cold) & 0.47 & \\
\hline \multirow[t]{4}{*}{ a-Monoacetin } & Neem (hot) & 5.48 & $\begin{array}{l}\text { Antifungal agent (http://chemicalland21.com/ industrial- } \\
\text { chem/plasticizer/MONOACETIN.htm) }\end{array}$ \\
\hline & Simarouba (hot) & 2.48 & \\
\hline & Madhuca (hot) & 1.5 & \\
\hline & Simarouba (cold) & 1.03 & \\
\hline Methyl gallate & Neem (hot) & 0.39 & $\begin{array}{l}\text { Antioxidant (Lubis et al. 2018), anti-HIV (Wang et al. 2014), } \\
\text { antimicrobial (Ahmed et al. 2017), Anti-obesity (Roh and } \\
\text { Jung 2012) }\end{array}$ \\
\hline Vinyl sulfide & Neem (hot) & 1.09 & Antioxidant (laniski et al. 2018) \\
\hline 5-Hydroxymethyl furfural & Neem (hot) & 2.68 & $\begin{array}{l}\text { Antioxidant and antiproliferative (Zhao et al. 2013) Treat- } \\
\text { ment of sickle cell disease (https://ec.europa.eu/health/ } \\
\text { documents/community-register/html/o1441.htm) }\end{array}$ \\
\hline 6-Hydroxy-4-methyl-3-phenylcoumarin & Neem (hot) & 0.24 & Antioxidant (Matos et al. 2015) \\
\hline Angelic acid & Neem (hot) & 1.4 & $\begin{array}{l}\text { Antioxidant (Ku 2018) } \\
\text { Strong pain-relieving and spasmolytic (Weiss 2001) seda- } \\
\text { tive and tonic against nervous problem, fever, colic, } \\
\text { heartburn, loss of appetite, gout, headache and other } \\
\text { health disturbances (Small 2006) }\end{array}$ \\
\hline Vanillic acid & Neem (hot) & 0.63 & $\begin{array}{l}\text { Antioxidant and antimicrobial (Kumar et al 2011; Yemis et al. } \\
\text { 2011) }\end{array}$ \\
\hline Binapacryl & Neem (cold) & 0.26 & Fungicide and miticide (Ward 1964) \\
\hline Indole & Neem (cold) & 1.94 & $\begin{array}{l}\text { Antidepressant, antioxidant, antimicrobial (Hamid et al. } \\
\text { 2017) }\end{array}$ \\
\hline \multirow[t]{3}{*}{ 2,4-Di-tert-butylphenol } & Simarouba (cold) & 0.48 & \\
\hline & Neem (cold) & 0.45 & $\begin{array}{l}\text { Antifungal activity (Dharni et al. 2014), antibacterial activity } \\
\text { (Dehpour et al. 2012; Aissaoui et al 2019), antioxidant and } \\
\text { anticancer (Choi et al. 2013), herbicidal (Halim et al. 2017) }\end{array}$ \\
\hline & Madhuca (cold) & 0.13 & \\
\hline Thymol & Madhuca (cold) & 0.21 & $\begin{array}{l}\text { Antibacterial, antifungal, antioxidant, antiseptic, antitumor, } \\
\text { anti-inflammatory, anti-hyperlipidaemia (Marchese et al. } \\
\text { 2016) }\end{array}$ \\
\hline 7-Methyl-Z-tetradecen-1-ol acetate & Madhuca (cold) & 0.52 & $\begin{array}{l}\text { Anticancer, anti-inflammatory, hepatoprotective (Hameed } \\
\text { et al. 2015) }\end{array}$ \\
\hline Chloramben, methyl ester & Madhuca (cold) & 0.12 & Herbicide (Wehtje et al. 1992) \\
\hline Nonanal & Simarouba (cold) & 0.99 & $\begin{array}{l}\text { Antibacterial (Bisignano et al. 2001), Antifungal (Zhang et al. } \\
\text { 2017) Antidiarrheal (Miguel et al. 2008) }\end{array}$ \\
\hline
\end{tabular}


Table 3 (continued)

\begin{tabular}{|c|c|c|c|}
\hline Phytochemicals & $\begin{array}{l}\text { Oil-cakes } \\
\text { and methods } \\
\text { of extraction }\end{array}$ & Abundancy (\%) & Bioactivity \\
\hline Xylitol & Simarouba (cold) & 0.03 & $\begin{array}{l}\text { Antioxidant (Kang et al. 2007), Antibacterial (Tapiainen et al. } \\
\text { 2001), Sweetener in oral hygiene preparations (Nayak } \\
\text { et al. 2014) }\end{array}$ \\
\hline Trans-2-Decenal & Simarouba (cold) & 1.36 & $\begin{array}{l}\text { Antimicrobial and insecticidal Nematicidal (Caboni et al. } \\
\text { 2012) }\end{array}$ \\
\hline Mevalolactone & Simarouba (hot) & 1.38 & $\begin{array}{l}\text { Antibacterial (Scopel et al. 2014) Phytotoxic (Varejão and } \\
\text { Demuner 2013) }\end{array}$ \\
\hline Pentadecanoic acid & Neem (cold) & 1.18 & Antioxidant (Al-Douri and Shakya 2019) \\
\hline Benzothiazole, 2-(2-hydroxyethylthio) & Neem (cold) & 4.91 & Anthelmintic activity (Lucie et al. 2013) \\
\hline Heptadecanoic acid & Neem (cold) & 1.07 & Antioxidant (Ponnamma and Manjunath 2012) \\
\hline Cyclic octaatomic sulfur & Neem (cold) & 0.26 & $\begin{array}{l}\text { Antioxidant, antimicrobial (Ojinnaka et al. 2015);treatment } \\
\text { of dandruff, acne, hay fever, common cold, scaly and red } \\
\text { skin patches (http://www.drugbank.ca/drugs/DB09353) }\end{array}$ \\
\hline \multirow[t]{3}{*}{ Oleic Acid } & Simarouba (cold) & 2.69 & $\begin{array}{l}\text { Protects against cardiovascular insulin resistance (Perdomo } \\
\text { et al. 2015), maintain a balance of body weight, reduce } \\
\text { serum blood cholesterol and pressure (Singh and Singh } \\
\text { 1991) }\end{array}$ \\
\hline & Madhuca (hot) & 1.22 & \\
\hline & Madhuca (cold) & 0.75 & \\
\hline \multirow[t]{3}{*}{ Stearic acid } & Madhuca (cold) & 3.15 & $\begin{array}{l}\text { Antimicrobial activity, antidepressant activity (Jubie et al. } \\
\text { 2012) pharmaceuticals and cosmetics, ointments (Lar- } \\
\text { ranaga 2016) }\end{array}$ \\
\hline & Simarouba (cold) & 0.89 & \\
\hline & Madhuca (hot) & 0.89 & \\
\hline Linoleic acid & Madhuca (cold) & 3.02 & $\begin{array}{l}\text { Antibacterial (Zheng et al. 2005) Antifungal and antioxidant } \\
\text { (Pinto et al. 2017) }\end{array}$ \\
\hline 2-Phenyl-4-anilino-6[1H]-pyrimidinone & Madhuca (cold) & 3.54 & Cytotoxic, Antimicrobial (Awadallah et al. 2013) \\
\hline Canthin-6-one & Simarouba (cold) & 2.02 & $\begin{array}{l}\text { Antimicrobial (Gazoni et al. 2018) Bacteriostatic (Jiang and } \\
\text { Zhou 2008), Anti- HIV, anticancer (Ammirante et al. 2006) }\end{array}$ \\
\hline Methyl 13-methyltetradecanoate & Neem (cold) & 0.25 & Anticancerous (https://pubchem.ncbi.nlm.nih.gov) \\
\hline Palmitic acid, methyl ester & Madhuca (cold) & 5.77 & $\begin{array}{l}\text { Vasodilator and neuroprotection in cardiac arrest (Lee et al. } \\
\text { 2018) }\end{array}$ \\
\hline Linoleic acid, methyl ester & Madhuca (cold) & 7.28 & Antifungal, antioxidant, antibacterial (Pinto et al. 2017) \\
\hline Elaidic acid, methyl ester & Madhuca (cold) & 5.68 & Synthesis of Cephalosporin antibiotics (Kirk-Orthmer 1991) \\
\hline \multirow[t]{2}{*}{ Dibutyl phthalate } & Neem (cold) & 4.07 & $\begin{array}{l}\text { Antibacterial (Khatiwora et al. 2012) phytotoxic (Millar and } \\
\text { Hannay 1986) }\end{array}$ \\
\hline & Simarouba (cold) & 4.74 & \\
\hline \multirow[t]{4}{*}{ Diisooctyl phthalate } & Neem (cold) & 9.41 & Antimicrobial (Zellagui et al. 2012) \\
\hline & Madhuca (cold) & 3.96 & \\
\hline & Madhuca (hot) & 1.19 & \\
\hline & Simarouba (cold) & 4.13 & \\
\hline
\end{tabular}

The cyclic voltammetry is a powerful electrochemical technique employed to investigate the reduction and oxidation potential of molecular species (Suliborska et al. 2019). This method correlated with the antioxidant assays by chemical and spectrometric means (Martinez et al. 2006; Keffous et al. 2016). Firuzi et al. (2005) observed that there was a correlation between electrochemical activity and redox potential of molecules/compounds with antioxidant properties. In the present study, maximum peaks were observed at relatively low potential $(\mathrm{Epa}<0.45 \mathrm{~V})$. It is found that compounds with strong scavenging capacities are oxidized at relatively low potential (Sousa et al. 2004). Simic et al. (2007) demonstrated that compounds with little Epa $(<0.45 \mathrm{~V})$ act as high antioxidants and with high Epa $(>0.45 \mathrm{~V})$ act as prooxidants. The observed peaks in the oil-seed cake extracts indicated the presence of low molecular weight antioxidants. According to Born et al. (1996), compounds with 
catechol group oxidized below $0.4 \mathrm{~V}$ and compounds having one or two phenolic groups showed antioxidant potential between 0.45 and $0.8 \mathrm{~V}$.

Based on the above studies, some of the constituents revealed by GC-MS are biologically active compounds. They were proven to possess pharmacologic activities that may contribute to the healing potential of the cake extracts. The major chemicals include glycerine in madhuca, and neem cake has antibacterial activity (Nalawade et al. 2015). In the case of simarouba cake extract, diacetone and hydroxyl ketone were documented as an antioxidant and anticancer agent (Zhang et al. 2015; Lyantagaye 2013; Kawsar et al. 2015). The GC-MS profile of the extracts revealed the presence of potential antioxidants (Table 3). The hot neem extract contained previously known antioxidants that includes methyl gallate (Lubis et al. 2018), vinyl sulphide (Ianiski et al. 2018), 5, hydroxymethylfurfural (Zhao et al. 2013), 6-hydroxyl-3-phenyl coumarin (Matos et al. 2015), cyclic octa atomic sulfur (Ojinnaka et al. 2015). The anti-HIV metabolites include methyl gallate $(0.39 \%)$, canthin-6-one $(2.02 \%)$ from neem hot and simarouba cold acetone extracts, respectively (Guvensen et al. 2019; Wang et al. 2014; Ahmed et al. 2017), while 2,4-di-tert-butylphenol and vanillic acid are also anticancer agents besides its antimicrobial, antioxidants activity (Gazoni et al. 2018; Yemis et al. 2011; Dehpour et al. 2012). On the other hand, angelic acid is identified as the potent antioxidants, spasmolytic, besides its usefulness to treat nervous problems (Varsha et al. 2015). Several compounds listed are also reported with pharmaceutical applications (Table 3).

\section{Conclusion}

This study demonstrated that extracts from neem, madhuca, and simarouba oil-seed cakes had antimicrobial activities against significant bacterial and fungal isolates with clinical or agricultural importance in the highest concentration $(200 \%)$. The oil-seed cakes contained a variety of phytochemicals with biological significance. The oil-seed cakes could be exploited for chemicals that find application as antimicrobial agents in new drugs for the treatment of infectious diseases caused by pathogens and for the remedy of phytopathogenic diseases responsible for yield reduction. The isolation and utilization of herbicidal compounds (Halim et al. 2017) from oil cakes of simarouba and madhuca could be a promising strategy in organic farming practices. Further studies are required to enhance the activity of oil-seed extracts and study the mode of action of the bioactive compounds individually and in combination. The present investigation highlights the utilization of bio-waste for the development of new environmentally safe antimicrobial and antioxidant agents of plant origin.

\begin{abstract}
Abbreviations
ZI: Zone of inhibition; Epa: Anodic peak potential; SE: Standard error; GC-MS: Gas Chromatography Mass Spectrometry; CV: Cyclic Voltammetry; DMSO: Dimethyl sulfoxide; MTCC: Microbial Type Culture Collection; ID: Internal diameter; Da: Daltons; min: Minutes; NIST: National Institute of Standards and Technology; mm: Millimetre; $\mathrm{Vs}^{-1}$ : Volts per second; $\mathrm{V}$ : Volt.
\end{abstract}

\section{Acknowledgements}

The first author gratefully acknowledges the financial support from the Department of Science and Technology, under the INSPIRE scheme, New Delhi, India.

\section{Authors' contributions \\ VUA collection of oil-seed cakes, extraction and fractionation of metabolites and analysis and preparation of the manuscript. MBS designed the meth- odology revision of the manuscript. BG and KBE provide a laboratory facility and revised the manuscript, and all authors have read and approved the manuscript.}

\section{Funding}

The financial support was obtained from the Department of Science and Technology under the INSPIRE scheme, New Delhi, India.

\section{Availability of data and materials}

All data generated or analyzed during this study are included in this article.

Ethics approval and consent to participate

Not applicable.

\section{Consent for publication}

Not applicable.

\section{Competing interests}

The authors declare that they have no competing interests.

\section{Author details}

${ }^{1}$ Department of PG Studies and Research in Applied Botany, Jnana Sahyadri, Kuvempu University, Shankaraghatta, Shivamogga 577 451, India. ${ }^{2}$ Department of Forestry and Environmental Science, University of Agricultural Sciences, GKVK Campus, Bangalore 560065, India.

Received: 23 September 2020 Accepted: 2 February 2021

Published online: 15 February 2021

\section{References}

Abd Ek-Raheem R, Shanshoury E, Sabha M, El-Sabbagh HA, Emara SHE (2014) Occurrence of mould, toxicogenic capability of Aspergillus flavus and levels of aflatoxins in maize, wheat, rice and peanut from markets in central delta provinces. Egypt Int J Curr Microbiol Appl Sci 3:852-865

Adeshina GO, Stephan A, Onaolapo JA, Ehinmidu JA, Odama LE (2011) Effect of heat on the antimicrobial activity of Alchornea cordifolia leaf extracts. Int J res Appl sci eng technol 5:227-232

Ahmed MD, Taher M, Maimusa AH, Rezali MF, and Mahmud MIAM (2017) Antimicrobial activity of methyl gallate isolated from the leaves of Glochidion superbum against hospital isolates of methicillin-resistant Staphylococcus aureus. Nat Prod 23:5-8. https://doi.org/10.20307/ nps.2017.23.1.5

Ahsan T, Chen J, Zhao X, Irfanand M, Wu Y (2017) Extraction and identification of bioactive compounds (eicosane and dibutyl phthalate) produced by Streptomyces strain KX852460 for the biological control of Rhizoctonia solani AG-3 strain KX852461 to control target spot disease in tobacco leaf. AMB Exp 7:54 https://doi.org/10.1186/s1356 8-017-0351-z

Aissaoui N, Mahjoubi M, Nas F, Mghirbi O, Arab M, Souissi Y et al (2019) Antibacterial potential of 2,4-di-tert-butylphenol and calixarene-based prodrugs from thermophilic Bacillus licheniformis isolated in Algerian 
hot spring. Geomicrobiol J 36:53-62. https://doi.org/10.1080/01490 451.2018 .1503377

Akintayo ET (2004) Characteristics and composition of Parkia biglobbossa and Jatropha curcas oils and cakes. Bioresource Technol 92:307-310. https:// doi.org/10.1016/S0960-8524(03)00197-4

Al-Douri N, Shakya AK (2019) Fatty acids analysis and antioxidant activity of a lipid extract obtained from Mercurialis annua L. Grown Wildly in Jordan. Acta Poloniae Pharmaceutica-Drug Res 76:275-281. https://doi. org/10.32383/appdr/97344

Ammirante M, Giacomo RD, Martino LD, Rosati A, Festa M, Gentilella A (2006) 1-Methoxy-Canthin-6-One Induces C-Jun NH2-Terminal Kinasedependent apoptosis and synergizes with tumor necrosis factorrelated apoptosis-inducing ligand activity in human neoplastic cells of hematopoietic or endodermal origin. Cancer Res 66:8. https://doi. org/10.1158/0008-5472.CAN-05-3895

Arulpriya P Lalitha P, Hemalatha (2010) In-vitro antioxidant testing of the extracts of Samanea saman (Jacq.) Merr. Stamford J Pharm Sci. 3(1). https://doi.org/10.3329/sjps.v3i1.6792

Ashraf MS, Khan TA (2010) Integrated approach for the management of Meloidogyne javanica on eggplant using oil cakes and biocontrol agents. Arch Phytopathol Plant Protection 43:609-614. https://doi. org/10.1080/03235400801972434

Awadallah FM, Piazza GA, Gary BD, Keeton AB, Canzoneri JC (2013) Synthesis of some dihydro pyrimidine-based compounds bearing pyrazoline moiety and evaluation of their antiproliferative activity. Eur J Med Chem 70:273-279

Bauer AW, Kirby WM, Sheriss JC, Turck M (1966) Antibiotic susceptibility testing by a standardized single disk method. Am J Clin Pathol 45:493-496

Bisignano G, Laganà MG, Trombetta D, Arena S, Nostro A, Uccella N, Mazzanti G, Saija A (2001) In vitro antibacterial activity of some aliphatic aldehydes from Olea europaea L. FEMS Microbiol Lett 198:9-13. https://doi. org/10.1111/j.1574-6968.2001.tb10611.x

Born M, Carrupt PA, Zini R, Brée F, Tillement JP, Hostettmann K, Testa B (1996) Electrochemical behavior and antioxidant activity of some natural polyphenols. Helv Chim Acta 79:1147-1158. https://doi.org/10.1002/ hlca.19960790422

Caboni P, Ntalli N, Aissani N, Cavoski I, Angioni A (2012) Nematicidal activity of $(\mathrm{E}, \mathrm{E})$-2,4-decadienal and (E)-2-decenal from Ailanthus altissima against Meloidogynejavanica. JAgr Food Chem 60:1146-1151. https://doi. org/10.1021/jf2044586

Calderone RA, Clancy CJ (2012) Candida and Candidiasis: ASM Press, Washington, $\mathrm{DC}$

Choi SJ, Kim JK, Kim HK, Harris K, Kim C-J, Park GG, Park C-S, Shin D-H (2013) 2,4-Di--butylphenol from Sweet Potato Protects Against Oxidative Stress in PC12 Cells and in Mice. J Med Food 16(11):977-983

Chung KT, Lu Z, Chou MW (1998) Mechanism of inhibition of tannic acid and released compounds on the growth of intestinal bacteria. Food Chem Toxicol 36:1053-1060. https://doi.org/10.1016/s0278-6915(98)00086-6

Crouse GD (1998) Pesticides: managing risks and optimizing benefits. Washington (DC): ACS Symposium Series 734, American Chemical Society. Natural products as leads for new pesticides with reduced risk pp 80-95

Culcuoglu E, Unay E, Karaosmanoglu F (2002) Rapeseed cake as a biomass source. Energy Sources 24:329-336. https://doi.org/10.1080/00908 310252888709

Cushine TP, Lamb AJ (2005) Antimicrobial activity of flavonoids. Int J Antimicrob 26: 343-356. https://doi.org/10.1016/j.ijantimicag.2005.09.002

Das K, Tiwari RKS, Shrivastava DK (2010) Techniques for evaluation of medicinal plant products as antimicrobial agent: current methods and future trends. J Med Plant Res 4:104-111

Dehpour AA, Yousefian M, Jafary Kelarijani SA, Koshmoo M, Mirzanegad S, Mahdavi V, Javad Bayani MJ (2012) Antibacterial activity and composition of essential oils of flower Allium rotundum. Adv Environ Biol 6:1020-1025

Dharni S, Sanchita Maurya A, Samad A, Srivastava SK, Sharma A, Patra DD (2014) Purification, characterization, and in vitro activity of 2,4-di-tertbutylphenol from Pseudomonas monteilii PsF84: conformational and molecular docking studies. J Agric Food Chem 62:6138-6146. https:// doi.org/10.1021/jf5001138
Eloff JN (1998) Which extract should be used for the screening and isolation of antimicrobial components from plants? J Ethnopharmacol 60:1-8. https://doi.org/10.1016/s0378-8741(97)00123-2

Firuzi O, Lacanna A, Petrucci R, Marrosu G, Saso L (2005) Evaluation of the antioxidant activity of flavonoids by "ferric reducing antioxidant power" assay and cyclic voltammetry. Biochim Biophys Acta 18:1721(1-3):17484 http://doi.org/https://doi.org/10.1016/j.bbagen.2004.11.001

Gazoni VF, Baloguna SO, Arunachalama K, Darley Oliveira M, Filho CV, Lima SR, Colode EM et al (2018) Assessment of toxicity and differential antimicrobial activity of methanol extract of rhizome of Simaba ferruginea A. St.-Hil and its isolate canthin-6-one. J Ethnopharmacol 223:122-134

Ghoshal S, Krishna Prasad BN, Lakshmi V (1996) Antiamoebic activity of Piper longum fruits against Entamoeba histolytica in vitro and in vivo. J Ethnopharmacol 50:167-170. https://doi.org/10.1016/0378-8741(96)01382 $-7$

Gorniak I, Bartoszewski R, Kroliczewsk J (2019) Comprehensive review of antimicrobial activities of plant flavonoids. Phytochem Rev 18:241-272

Govindachari TR (1992) Chemica and biological investigations on Azadirachta indica (the neem tree). Current Sci 63:117-122

Govindaraju K, Darukeshwara J, Alok K, Srivastava (2009) Studies on protein characteristics and toxic constituents of Simaruba glauca oil seed meal. Food Chem Technol 47: 1327-1332. https://doi.org/10.1016/j. fct.2009.03.006

Gubitz GM, Mittelbach M, Trabi M (1999) Exploitation of tropical oil seed plant Jatropha curcas L. Bioresour Technol 67:73-82. https://doi.org/10.1016/ S0960-8524(99)00069-3

Guvensen NC, Keskin D Güneş H Oktay KM, Yıldırım H (2019). Antimicrobial property and antiproliferative activity of Centaurea babylonica (L.) on human carcinomas and cervical cancer cell lines. Ann Agric Environ Med 26:290-297. https://doi.org/10.26444/aaem/108563

Halim NA, Razak SBA, Simbak N, Seng CT (2017) 2,4-Di-tert-butylphenolinduced leaf physiological and ultrastructural changes in chloroplasts of weedy plants. S Afr J Bot 112:89-94. https://doi.org/10.1016/j. sajb.2017.05.022

Hameed IH, Hussein HJ, Kareem M, Hamad N (2015) Identification of five newly described bioactive chemical compounds in Methanolic extract of Mentha viridis by using gas chromatography-mass spectrometry (GC-MS). J Pharmacognosy Phytother 7:107-125. https://doi. org/10.5897/JPP2015.0349

Hamid HA, Ramli ANM, Yusoff MM (2017) Indole alkaloids from plants as potential leads for antidepressant drugs: a minireview. Front Pharmacol. https://doi.org/10.3389/fphar.2017.00096

Harold CN (1974) Antimicrobial activity and human pathology of Amoxicillin. J InfectDis 129:123-131

laniski FR, Bassaco MM, Vogt AG, Reis AS, Pinz MP, Voss GT, de Oliveira RL et al (2018) Antinociceptive property of vinyl sulfides in spite of their weak antioxidant activity. Med Chem Res 27:46-51

Jiang MX, Zhou YJ (2008) canthin-6-one alkaloids from Picrasma quassinoids and their cytotoxic activity. J Asian Nat Prod Res 10:1009-1012. https:// doi.org/10.1080/10286020802277956

Joshi B, Sah GP, Basnet BB, Bhatt M, Sharma D, Subedi K, Pandey J, Malla R (2011) Phytochemical extraction and antimicrobial properties of different medicinal plants: Ocimum sanctum (Tulsi), Eugenia caryophyllata (Clove), Achyranthes bidentate (Datiwan) and Azadirachta indica (Neem). J Microbial Antimicrob 3:1-7

Jubie S, Ramesh PN, Dhanabal P, Kalirajan R, Muruganantham N, Antony AS (2012) Synthesis, antidepressant and antimicrobial activities of some novel stearic acid analogues. Eur J Med Chem 54:931-5. https://doi. org/10.1016/j.ejmech.2012.06.025

Kameswaran M, Raghunandan S (2009) Saprophytic mycotic infections of the nose and paranasal sinuses. Otorhinolaryngology: Int J 1:25-31. https:// doi.org/10.4103/0975-2870.122775

Kang KW, Kwak SH, Yun SY, Kim SK (2007) Evaluation of antioxidant activity of sugar alcohols using TOSC (total oxy-radical scavenging capacity) assay. J Toxicol Pub Health 23:143-150

Kathuria N, Singh KP (2015) Antibacterial activities of leaves extract of Indian butter tree (Madhuca indica). Int Res J Pharm 6:805-807. https://doi. org/10.7897/2230-8407.0612156

Kavathekar KY (2003) Neem in India, NISCAIR, New Delhi 21 - 23 
Kavitha G, Karuna R, Sasidhar RB (2014) Inhibitory role of neem seed kernel extracts and terpenoids on growth and aflatoxin production by Aspergillus parasiticus (NRRL 2999) Indian J Nat Prod Resour 1:20-33

Kawsar SMA, Uddin S, Manchur MA, Fujii Y, Ozeki Y (2015) Acylation of D-glucose derivatives over $\mathrm{C} 5 \mathrm{H} 5 \mathrm{~N}$ : spectral characterization and in vitro antibacterial activities. Int J Biol Chem 9:269-282. https://doi. org/10.3923/ijbc.2015.269.282

Keffous F, Belboukhari N, Sekkoum K, Djeradi H, Hassan CA, Aboul-Enein Y (2016) Determination of the antioxidant activity of Limoniastrum feei aqueous extract by chemical and electrochemical methods. Cogent Chem 2:1186141. https://doi.org/10.1080/23312009.2016.1186141

Khatiwora E, Vaishali B, Adsul KM, Deshpande NR, Kashalkar RV (2012) Antibacterial activity of Dibutyl Phthalate: a secondary metabolite isolated from Ipomoea carnea stem. J Pharm Res 5:150-152

Kirby GC, 'Neill MJO, Phillipson JD, Warhurst DC (1989) In vitro studies on the mode of action of quassinoids with activity against chloroquine-resistant Plasmodium falciparum. Biochem Pharmacol 38:4367-74 https:// doi.org/10.1016/0006-2952(89)90644-8

Kirk-Orthmer (1991) Encyclopedia of Chemical Technology, vol 1, 4th edn. John Wiley and Sons, NewYork, NY, p 56

Knothe G (2006) Analyzing biodiesel: standards and other methods. J Am Oil Chem Soc 9:847-853. https://doi.org/10.1007/s11746-006-5033-y

Ku J (2018) Photodamage attenuation effect by angelic acid in UVA-irradiation-induced damages in normal human dermal fibroblast. Biomed Dermatol 2:8

Kumar KP, Vidyasagar G, Ramakrishna D, Reddy IM, Gupta VA, Raidu C (2011) Screening of Madhuca indica for antidiabetic activity in streptozotocin and streptozotocin-nicotinamide-induced diabetic rats. Int J Pharmaceutical Technol Res 3:1073-1077

Kumari A, Kumar R, Maurya S, Choudhary JS, Kumar S (2013) Antifungal afficiency of aqueous extracts of neem cake, karanja cake, and vermicompost against some phytopathogenic fungi. Bioscan 8:671-674

Larranaga MD, Lewis RJS, Lewis RA (2016) Hawley's condensed chemical dictionary 16th edition. Wiley, Hoboken, p 1273

Lee RH, Silva CA, Possoita HE, Lernerd FM, Chena P, Azizbayeva R (2018) Palmitic acid methyl ester is a novel neuroprotective agent against cardiac arrest. Prostaglandins Leukotriens and essential fatty acid. PLEFA 147: 6-14

Lubis MY, Siburian R, Marpaung L, Simanjuntak P, Nasution MP (2018) Methyl gallate from Jiringa (Archidendron jiringa) and antioxidant activity. Asian J Pharm Clin Res 11: 346-350 https://doi.org/10.22159/ajpcr.2017. v11i1.21637

Lucie AT, Dogo S, Béranger LDP, Florent BOS, Talla GM, Anna T et al (2013) Chemical characterization and insecticidal activity of ethyl acetate and dichloromethane extracts of Drypetes gossweileri against Sitophilus zeamais, Tribolium castaneum and Rhyzopertha dominica. J Life Sci 11:1030-1040. https://doi.org/10.5539/ijb.v8n2p23

Lyantagaye SL (2013) Methyl-a-D-glucopyranoside from Tulbghia violacea extract induces apoptosis in vitro in cancer cells. Bangladesh J Pharmacol 8:93-101. https://doi.org/10.3329/bjp.v8i2.13717

Makkar HPS, Aderibigbe AO, Becker K (1998) Comparative evaluation of non-toxic and toxic varieties of Jatropha curcas for chemical composition, digestibility, protein degradability, and toxic factors. Food Chem 62:207-215. https://doi.org/10.1016/S0308-8146(97)00183-0

Mansi P, Gaikwad DK (2011) A critical review on medicinally important oil yielding plant Laxmitaru (Simaruba glauca DC). J Pharma Sci Res. 3:1195-1213

Marchese A, Orhan IE, Daglia Nabavi SF, Nabavi SM (2016) Antibacterial and antifungal activities of thymol: a brief review of the literature. Food Chem 210:402-414. https://doi.org/10.1016/j.foodchem.2016.04.111

Martin C, Moure A, Martin G, Carrillo E, Dominguez H, Parajo JC (2010) Fractional characterization of jatropha, neem, moringa, triperma, castor, castor and candlenut seeds as potential feedstocks for biodiesel production in Cuba. Biomass Bioenerg 34:5333-5538

Martinez S, Valek L, Resetic J, Ruzic DF (2006) Cyclic voltammetry study of plasma antioxidant capacity - Comparison with the DPPH and TAS spectrophotometric methods. J Electroanal. Chem 588:68-73 https:// doi.org/10.1016/j.jelechem.2005.12.016

Matos MJ, Santana L, Uriarte E, Abreu OA, Molina E, Yordi EG (2015) Coumarins: an important class of phytochemicals. https://doi.org/10.5772/59982
Millar DJ, Hannay JW (1986) Phytotoxicity of phthalate plasticisers: 2 site and mode of action. J Exp Bot 37:898-908

Nalawade TM, Bhat K, Sogi SH (2015) Bactericidal activity of propylene glycol, glycerine, polyethylene glycol 400, and polyethylene glycol 1000 against selected microorganisms. J Int Soc Prev Community Dent 5:114-9. https://doi.org/10.4103/2231-0762.155736

Nayak PA, Nayak UA, Khandelwal V (2014) The effect of xylitol on dental caries and oral flora. Clin Cosmet Investig Dent 6:89-94. https://doi. org/10.2147/CCIDE.S55761

Nurhannan MY, Azimahotol HLP, Mohd Ilham A, Mohd Shukri MA (2005) Cytotoxic effects of the root extracts of Eurycoma longifolia Jack. Phytopathol Res 19:994-996

Ojinnaka CM, Kelechi I, Nwachukwu EMN (2015) The Chemical Constituents and Bioactivity of the seed (Fruit) extracts of Buchholzia Coriacea Engler (Capparaceae). J Appl Sci Environ Manag 19:795-801

Padhi SK, Singh RK (2011) Non-edible oil as the potential source for the production of biodiesel in India: a review. J Chem Pharma Res 3:39-49

Parimala M, Shoba FG (2014) In vitro antimicrobial activity and HPLC analysis of hydroalcoholic seed extract of Nymphaea nouchali Burn. f. BMC Complement Altern Med 14:361. https://doi.org/10.1186/1472-6882-14-361

Perdomo L, Beneit N, Otero YF, Escribano Ó, Díaz-Castroverde S GómezHernández A, Benito M (2015) Protective role of oleic acid against cardiovascular insulin resistance and in the early and late cellular atherosclerotic process. Cardiovasc Diabetol 14:75. https://doi.org/10.1186/ s12933-015-0237-9

Pinto MEA, Araújo SG, Morais MI, Sa NP, Lima CM, Rosa CA et al (2017) Antifungal and antioxidant activity of fatty acid methyl esters from vegetable oils. An Acad Bras Ciênc 89:1671-1681. https://doi.org/10.1590/00013765201720160908

Ponnamma SU, Manjunath K (2012) GC-MS Analysis of Phytocomponents in the Methanolic Extract of Justicia wynaadensis (Nees) T. Anders. Int Journal of Pharma Bio Sci 3:570-576

Prasad JS, Varaprasad KS, Rao VR, Srinivas RE, Sankar M (2005) Comparative efficiency of some oil seed cakes and extracts against Root-knot nematode (Meloidogyne graminicola) infection in rice. Nimatol Medit 33:191-194

Rahua J, Remes S, Heinonen M, Hopia A, Kahkonen M, Kujala T, Pihlaja K, Vuorela P (2000) Antimicrobial effects of Finnish plant extracts containing flavonoids and other phenolic compounds. Int J Food Microbiol 56:3-12. https://doi.org/10.21010/ajtcam.v14i2.19

Rameshchandran S, Singh SK, Larroche C, Soccol CR, Pandey A (2007) Oil cakes and their biotechnological applications. Bioresource Technol 98:2000-2009. https://doi.org/10.1016/j.biortech.2006.08.002

Rizvi R, Mahmood I, Tiyagi SA, Khan Z (2012) Conjoint effect of oil-seed cakes and Pseudomonas fluorescens on the growth of chickpea in relation to the management of plant-parasitic nematodes. Braz Arch Biol Technol 55:801-808. https://doi.org/10.1590/S1516-89132012000600001

Roh C, Jung U (2012) Screening of crude plant extracts with anti-obesity activity. Int J Mol Sci 13:1710-1719. https://doi.org/10.3390/ijms13021710

Rubila S, Ranghanathan TV (2014) Evaluation of phytochemical constituents in various heat treatments of Zingiber officinale Rosce and in vitro antioxidant assay system. Int res J biol Sci 3:54-58

Saha S, Walia S, Kumar J, Parmer BS, Prasad D (2010) Synergistic/ potential interaction between nematostatic constituents from Azadirachta indica, Madhuca indica, and Sapindus mukorossi. Arch Phytopathol Plant Prot 43:357-367. https://doi.org/10.1080/03235400701806328

Sarone P, Nicholetti M (2013) Antimicrobial activity of neem cake extract in a broth model mean system. Int J Environ Res Public health 10:32823295. https://doi.org/10.3390/ijerph10083282

Sasidharan S, Chen Y, Saravanan D, Sundram KML, Latha Y (2011) Extraction, isolation and characterization of bioactive compounds from plants extracts. Afr J Tradit Complement Altern Med 8:1-10

Scopel M, Abraham WR, Antunes AL, Henriques AT, Macedo AJ (2014) Mevalonolactone: an inhibitor of Staphylococcus epidermidis adherence and biofilm formation. Med Chem 10:246-251

Scott PT, Pregeji L, Chen N, Djordjevic Hadler JS, Gresshoff MA, Gresshoff PM (2008) Pongamia pinnata: an untappered resource for the biofuels industry of the future. Bioenergy Res 1:2-11. https://doi.org/10.1007/ s12155-008-9003-0

Severan ML (1953) Aceituno seed fat. J Am Oil Chem Soci 30:124-126 
Sharmin E, Ashraf SM, Ahmad S (2006) Synthesis, characterization, antibacterial and corrosion protective properties of epoxies, epoxy polyols and epoxy-polyurethane coating from linseed and Pongamia glabra seed oils. Int J Biol Macromol 40:407-22. https://doi.org/10.1016/j.ijbio mac.2006.10.002

Shimada T (2006) Salivary proteins as a defense against dietary tannins. J Chem Ecol 32: 1149-1163. https://doi.org/10.1007/s10886-006-9077-0

Shinde AB, Mulay YR (2015) Phytochemical and antibacterial properties of some selected Indian Medicinal plants. Int J Curr Microbiol Appl Sci 4:228-235

Simic A, Manojlovic D, Segan D, Todorovic M (2007) Electrochemical behaviour and antioxidant and prooxidant activity of natural phenolics 12:232740. https://doi.org/10.3390/12102327

Singh A, Singh IS (1991) Chemical evaluation of mahua (Madhuca indica) seed. Food Chem 40:221-228

Small E (2006) Culinary herbs, National Research Council Canada, ISBN 0-660$19073-7$, p. 288

Sousa WR, da Rocha C, Cardoso CL, Silva DHS, Zanoni MVB (2004) Determination of the relative contribution of phenolic antioxidants in orange juice by voltametric methods. J Food Comp Anal 17:619-633

Soxhlet F (1879) Die genichtsanalytische bestimmung des miichfcttos. Dingler Poly Tech J 232:461

Suliborska K, Baranowska M, Bartoszek A, Chrzanowski W and Namieśnik J (2019) Determination of antioxidant activity of Vitamin C by voltammetric methods. Proceedings 11:23. https://doi.org/10.3390/proce edings2019011023

Tapiainen T, Kontiokari T, Sammalkivi L, Ikäheimo I, Koskela M, Uhari M (2001) Effect of Xylitol on growth of Streptococcus pneumoniae in the presence of fructose and sorbitol. Antimicrob Agents Chemother 45:166-169. https://doi.org/10.1128/AAC.45.1.166-169.2001.

Tsuchiya H, Sato M, Miyazaki S, Fujiwara S, Tanigaki M, Ohyama T, Tanaka IM (1996) Comparative study on the antibacterial activity of phytochemical flavanones against methicillin-resistant Staphylococcus aureus. J Ethnopharmacol 50:27-34. https://doi.org/10.1016/0378-8741(96)85514-0

Valdes AF, Martinez JM, Lizama RC, Vermeersch M, Cos P, Maes L (2008) In vitro anti-microbial activity of the Cuban medicinal plants Simarouba glauca DC, Melaleuca leucadendron L and Artemisia absinthium L. Mem Inst Oswaldo Cruz. Rio de Janerio 103:615-618. https://doi.org/10.1590/ s0074-02762008000600019

Varejão EVV, Demuner AJ (2013) Phytotoxic effects of metabolites from Alternaria euphorbiicola against its host plant Euphorbia heterophylla. Quim Nova 36:1004-1007

Varsha KK, Devendra L, Shilpa G, Priya S, Pandey A, Nampoothiri KM (2015) 2,4-Di-tert-butyl phenol as the antifungal, antioxidant bioactive purified from a newly isolated Lactococcus sp. Int J Food Microbiol 211:44-50. https://doi.org/10.1016/j.jijfoodmicro.2015.06.025

Vinoth B, Manivasagaperumal R, Rajaravindran M (2012) Phytochemical analysis and antibacterial activity of Azadirachta indica A Juss. Int J Plant Sci 2:50-55
Wang CR, Zhou R, Ng TB, Wong JH, Qiao WT, Liu F (2014) First report on isolation of methyl gallate with antioxidant, anti-HIV-1 and HIV-1 enzyme inhibitory activities from a mushroom (Pholiota adiposa). Environmental Toxicology and Pharmacology 37: 626-637 https://doi.org/10.1016/j. etap.2014.01.023

Wani SP, Narayana YD, Ray TV (1982) Screening of fungicides invitro against Fusarium causing rot of gladolus corns. Indian. J Microbiol. 22:49-51

Ward JR (1964) Binapacryl: a new fungicide for the control of apple powdery mildew (Podosphaera leucotricha). Australian J Exp Agric Anim Husbandry 4:52-54

Wehtje G, Wilcut JW, Mcguire JA (1992) Paraquat phytotoxicity, absorption, and translocation in peanut and selected weeds as influenced by chloramben1. Weed Sci 40:471-476

Weiss RF (2001) Weiss's herbal medicine, Thieme, ISBN 1-58890-069-X pp. 46, 91,236

Write CW (2005) Traditional antimalarials and development of novel antimalarial drugs. J Ethnopharmacol 100:67-71. https://doi.org/10.1016/j. jep.2005.05.012

Yadav P, Singh D (2012) Madhuca longifolia (Sapotaceae): a review of its traditional uses, phytochemistry, and pharmacology. Int J Biomed Res 3:291-305. https://doi.org/10.7439/ijbr.v3i7.292

Yemis GP, Pagotto F, Bach S, Delaquis P (2011) Effect of vanillin, ethyl vanillin, and vanillic acid on the growth and heat resistance of Cronobacter Species. J Food Prot 74:2062-2069 https://doi.org/10.4315/0362-028x. jfp-11-230

Zellagui A, Gherraf N, Ladjel S, Hameurlaine S (2012) Chemical composition and antibacterial activity of the essential oils from Launaea resedifolia $\mathrm{L}$. Org Med Chem Lett 2:2

Zhang Y, Smith P, Maximova SN, Guiltinan MJ (2015) Application of glycerol as a foliar spray activates the defense response and enhances disease resistance of Theobroma cacao. Mol Plant Pathol 16:27-37

Zhang J, Sun H, Chen S, Zeng L and Wang T (2017) Anti-fungal activity, mechanism studies on a-Phellandrene and nonanal against Penicillium cyclopium. Bot Stud 58:13. https://doi.org/10.1186/s40529-017-0168-8

Zhao L, Chen J, Su J, Li L, Hu S, Li B, Zhang X, Xu Z, Chen T (2013) In vitro antioxidant and antiproliferative activities of 5-hydroxymethylfurfural. J Agric Food Chem 61:10604-11. https://doi.org/10.1021/jf403098y

Zheng CJ, Yoo JS, Lee TG, Cho HY, Kim YH, Kim WG (2005) Fatty acid synthesis is a target for antibacterial activity of unsaturated fatty acids. FEBS Lett 579:5157-62. https://doi.org/10.1016/j.febslet.2005.08.028

\section{Publisher's Note}

Springer Nature remains neutral with regard to jurisdictional claims in published maps and institutional affiliations.

\section{Submit your manuscript to a SpringerOpen ${ }^{\circ}$ journal and benefit from:}

- Convenient online submission

- Rigorous peer review

- Open access: articles freely available online

- High visibility within the field

- Retaining the copyright to your article

Submit your next manuscript at $\boldsymbol{\nabla}$ springeropen.com 